Res Publica. Revista de Historia de las Ideas Políticas ISSN-e: 1989-6115

\title{
Horizontes de liberalismo en la crisis de la Restauración: de Ortega a María Zambrano
}

\author{
David Soto Carrasco*
}

Recibido: 21 de junio de 2018 / Aceptado: 14 de diciembre de 2018

Resumen. El presente trabajo analiza el pensamiento liberal de Ortega y Gasset y María Zambrano ante la crisis de los años 30 y sus derroteros teórico-prácticos hasta la proclamación de la II República. En el primer epígrafe, se enmarca la reflexión de Ortega en torno a la Restauración dentro del ciclo europeo de desarrollo del hombre-masa y la necesidad de levantar una élite rectora de la cultura y de la vida. En un segundo momento, se reflexiona sobre las propuestas de superación fascista de la Dictadura, para presentar el análisis de Ortega sobre el fascismo, como culminación del proceso de rebelión de las masas. Ortega, ante la situación de la monarquía española, seguiría atado a la idea de organizar la decencia nacional. En este espacio, la Agrupación al Servicio de la República jugará una papel determinante como intento de revitalizar un cierto liberalismo de corte republicano. Por su parte, Zambrano apostó por un liberalismo de influencia socialista y comunitarista capaz de acometer la cuestión social bajo el mandato de una aristocracia espiritual. En este contexto, la incapacidad de Ortega de erigirse como maestro de una generación llevará a algunos de sus discípulos más exaltados a fundar el Frente Español, un partido nacional, que aspiraba a superar las divisiones de clases. Otros discípulos tomarán caminos más radicales.

Palabras clave: liberalismo; Restauración; fascismo; Ortega y Gasset; María Zambrano.

\section{[en] Horizons of Liberalism in the Crisis of the Restoration: from Ortega to María Zambrano}

\begin{abstract}
This paper analyzes the liberal thinking of Ortega y Gasset and María Zambrano before the crisis of the 30s and its theoretical-practical developmests until the proclamation of the Second Spanish Republic. In the first section, Ortega's reflection on Restoration is framed within the European cycle of the development of the "mass-man" and the need to raise a governing elite of culture and life. In a second moment, it reflects on the proposals for fascist overcoming of the dictatorship, to present Ortega's analysis of fascism, as the culmination of the process of revolt of the masses. Ortega, in the face of the situation of the Spanish monarchy, would follow the idea of organizing national decency. In this context, the 'Agrupación al Servicio de la República' plays a decisive role, as an effort to revitalize a certain liberalism of a republican nature. For her part, Zambrano, more committed, will bet on a liberalism with socialist and communitarian influences, with the ability to tackle the social question under the mandate of a spiritual aristocracy. In this context, Ortega's inability to establish himself as a intelectual leader of a generation, to lead some of his most exalted disciples to found the "Frente Español", a national party, far beyond the class division. Other disciples will take more radical ways.
\end{abstract}

Keywords: Liberalism; Restoration; Fascism, Ortega y Gasset, María Zambrano.

\footnotetext{
* Universidad de Murcia davsoto@um.es
} 
Sumario. 1. El tema de nuestro tiempo: de la vida a las masas. 2. Ortega y la recepción del fascismo. 3. El liberalismo como puerta de salida a la Restauración. 4. La puesta en marcha de un partido algo más que liberal. 5. La monarquía debía ser destruida.

Cómo citar: Soto Carrasco, D. (2019). Horizontes de liberalismo en la crisis de la Restauración: de Ortega a María Zambrano, en Res Publica 22.1, 171-193

\section{El tema de nuestro tiempo: de la vida a las masas}

En 1933 Zambrano escribió en la revista de José Bergamín, Cruz y Raya, un amplio comentario a propósito del volumen de Obras de Ortega escritas entre 1914-1932, en el que reconoció una línea de continuidad entre Meditaciones del Quijote (1914) y los trabajos posteriores bajo una cierta filosofía de la vida ${ }^{1}$. La vida humana se revelaría para Zambrano como aquello que está detrás de todos los hechos de la realidad y aludiría al fondo último del que todas las cosas "emergen o brotan", impulsando al individuo a lo que debe ser, al "ideal". Frente a ella, la circunstancia o el mundo planteará al hombre el problema de vivir. Lo que le exigirá que la acometa como tarea, como esfuerzo o como aventura. Así, Zambrano vinculó sus primeras proyecciones filosóficas a los trabajos fundamentales de Ortega aparecidos durante estos años. Hay que recordar que El Tema de nuestro tiempo (1923), la segunda obra estrictamente filosófica de Ortega, aparecida dos años después de que publicara España invertebrada (1921), significará una continuación, pero a la vez un replanteamiento de la filosofía esbozada en Meditaciones, donde el filósofo ya afirmaba el carácter circunstancial de la vida: "Yo soy yo y mi circunstancia y si no la salvo a ella no me salvo yo". Allí, la circunstancia o la realidad se planteaba como un obstáculo para la libre emergencia del vivir, lo que exigía una voluntad de salvación que sólo era capaz de presentarse si se entroncaba con los ideales más altos de Cultura. Sin embargo, en 1923, la influencia de neokantismo se va a ir apagando para dar paso a un mayor de predominio de Nietzsche, que llevará a Ortega a un intentó de someter la razón a la vitalidad. Bajo este punto de vista, Ortega, y con él la propia Zambrano, como más tarde mostraremos, aseverará que sólo es posible una salvación racional para el individuo desde una filosofía que nace de y sirve a la vida. Bajo esta premisa, España invertebrada venía a mostrar la necesidad de salvación de la España vital que se petrificaba día a día bajo el peso de la oficial. Ortega retornó sobre la necesidad de acometer la tarea de un proceso de nacionalización ante un país que sufría un "proceso de disolución". Se trató de presentar un proyecto de organización nacional que tenía por centro a Castilla como aglutinante de todas y cada una de las partes de España en la medida que era la única capaz de construir "un proyecto sugestivo de vida en común". El problema de la Restauración era, según el parecer de Ortega, que Castilla llevaba siglos sin acometer grandes empresas. Se había limitado a conservar el pasado y en abortar todo proceso de innovación, perdiendo la relación con las otras regiones y abandonándolas a sí mismas ${ }^{2}$. Además, la nación se había disuelto

M. Zambrano, "Señal de vida. Obras de José Ortega y Gasset (1914-1932)”, Revista de Occidente 24-2, 1983, pp. 270-278. Se publicó originalmente en Cruz y Raya 2, 1933, pp. 145-154.

2 Cf. J. Ortega y Gasset, "España Invertebrada. Bosquejo de algunos pensamiento históricos", en Obras Completas. Tomo III (1917-1925). Madrid, Taurus, 2004, p. 441. 
en las diversas luchas entre clases, en el "imperio de las masas". Para el filósofo madrileño, toda posibilidad pasaba ahora por la acción directora y socializadora de las elites intelectuales y políticas que debían contribuir a un proyecto de regeneración nacional. Es más, si se hablaba de Castilla era en la medida en que poseía un "talento nacionalizador" que para el filósofo la historia española había demostrado ${ }^{3}$.

Sin embargo, la llegada de la Dictadura de Primo de Rivera cortaría el proyecto intelectual y político de un Ortega que pronto tomaría posición contra el nuevo régimen ${ }^{4}$. No obstante, a través de la problemática de la vida y su relación con la Cultura, influenciado por Simmel ${ }^{5}$, planteará la existencia de una crisis no sólo española, sino ya abiertamente europea. Precisamente, a través de su reflexión sobre la Razón vital concebida en El tema de nuestro tiempo acometerá la labor de volver a colocar la vida al mismo nivel que la razón, localizándola dentro de lo biológico y supeditándola a lo espontáneo. Si en Meditaciones del Quijote, la cultura y la vida eran realidades afines, siendo la cultura el momento de mayor "claridad y firmeza", en El tema de nuestro tiempo vida y cultura estarán enfrentadas. La crisis de Europa se debía en gran medida a que la cultura moderna había desplazado a la vida. "Lo

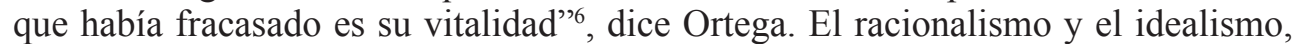
que habían dominado el continente desde el siglo XIX, habían destruido la fuente de inspiración y espontaneidad que hacen que una cultura esté viva. En su intento de salvar la verdad, el racionalismo había renunciado a la vida, negándole todo sentido. De modo que la razón se había impuesto de manera violenta sobre la vida ${ }^{7}$. Para Ortega, Kant lo declaró cuando advirtió que: "No es el entendimiento quien ha de regirse por el objeto, sino el objeto por el entendimiento" ${ }^{8 "}$. Del mismo modo, para Fichte, según el filósofo madrileño, el papel de la razón no era comprender lo real sino "crear modelos", lo que había provocado una inversión de la perspectiva espontánea, poniendo la realidad al servicio de la Idea ${ }^{9}$. Además, por su parte el relativismo había desvanecido el valor objetivo de la cultura para dejar paso a una vida sin dirección al carecer de ideales. Desde este punto de vista, la razón vital proyectada por Ortega tratará de consagrar la vida, haciendo de ella un principio rector de la Cultura. Así, toda posibilidad para Europa pasaba por el imperativo de construir una cultura basada en la recuperación de los valores vitales.

A finales de la década de los años veinte en el conocido curso titulado ¿Qué es filosofía? (1929), Ortega completó su concepto de vida con algunos matices que lo fijarían casi definitivamente. La vida no era un tipo de fenómeno biológico o psicológico que poseen ciertos individuos, sino la "realidad radical". La filosofía

En opinión de Elorza, el protagonismo asignado a Castilla encuentra antecedentes precisos en los trabajos de Ramón Menéndez Pidal y del Centro de Estudios Históricos, así como en el regeneracionismo de Joaquín Costa. Cf. A. Elorza, La razón y la sombra. Una lectura política de Ortega, Barcelona, Anagrama, 1994, pp. 146-147.

4 J. Ortega y Gasset, "Sobre la vieja política", El Sol, 27 de noviembre de 1923, en Obras Completas. Tomo III (1917-1925). Madrid, Taurus, 2004, pp. 550-555.

5 J. Ortega y Gasset, "El tema de nuestro tiempo", en Obras Completas. Tomo III (1917-1925). Madrid, Taurus, 2004, p. 581. Cf. N. Orringer, Ortega y sus fuentes germánicas, Madrid, Gredos, 1979, pp. 293-315.

$6 \quad$ Ibidem, p. 587.

7 J. Ortega y Gasset, "Ni vitalismo ni racionalismo", en Obras Completas. Tomo III (1917-1925). Madrid, Taurus, 2004, p. 727.

$8 \quad$ Ibidem, p. 723.

9 J. Ortega y Gasset, El tema de nuestro tiempo, op. cit., pp. 599-600. Cf. P. Cerezo, La voluntad de aventura: aproximamiento crítico al pensamiento de Ortega y Gasset, Barcelona, Editorial Ariel, 1984, pp. 258-259. 
debía apartarse del "imperialismo de la física"10, para arraigar en la vida. Contra la abstracción del racionalismo y contra el pragmatismo biologista, Ortega abogará por una filosofía que afirmará la necesidad de que el conocimiento esté asido a la vida. La filosofía debía en primer lugar, dar razón de los hechos vitales. Vivir consistirá en tratar con el mundo y dar cuenta de él. La vida se planteará entonces como problema, como quehacer, como tarea y, en última instancia, como naufragio. El mundo se abre como un horizonte en el que el hombre puede elegir libremente lo que hace, construyendo un "proyecto". En este espacio argumentativo nacerá el libro de Horizonte del Liberalismo de Zambrano.

En 1930, casi al mismo tiempo que la obra de Zambrano, verá la luz publicado en forma de libro La rebelión de las masas, aunque su contenido había sido anticipado en artículos y conferencias algunos años antes, como el propio Ortega recuerda en una nota. De hecho, en el "Prólogo para franceses" de 1937, advierte los cambios que se han producido, sobre todo los que afectan a los primeros capítulos, y subraya que: "El lector debería, al leerlos, retrotraerse a los años 1926-1928". Acertadamente, Julián Marías indicó que el libro nació en una generación pero vivió desde la cuna en otra bien distinta: en una época de politización ${ }^{11}$. Ortega habló allí de la crisis europea con el nacimiento del hombre-masa, como producto de una época que emergía de los desarrollos últimos del racionalismo y que dotaba a la sociedad de estabilidad, seguridad, y un relativo confort. A su modo de ver, Europa se había desvinculado de sus raíces creadoras, autoliquindándose culturalmente ${ }^{12}$. El desarrollo que el racionalismo había propiciado, había favorecido el aumento y la homogeneización de la población y la abundancia de bienes trasformando las sociedades no sólo en términos de política, sino también de experiencia vital y cultural. La sociedad se había masificado y las antiguas elites habían dejado de llevar acabo su tradicional actividad rectora. Dice Ortega: "Más que un hombre, es sólo un caparazón de hombre constituidos por meros idola fori carece de un dentro, de una intimidad suya, inexorable e inalienable, de un yo que no se pueda revocar"13. Bajo esta perspectiva, el hombre-masa se caracterizará por no tener propiamente ideas, sino representaciones. No tiene voluntad, sino que es dominado por sus apetitos que tiende a satisfacer a toda costa imponiéndosele. No vive por su propio esfuerzo, por tanto su vida deriva en existencia inauténtica. Vive una existencia impersonal y anónima, plana y homogénea sin destino posible, a merced de las circunstancias y de las corrientes dominantes ${ }^{14}$. En este sentido, para Ortega, era imposible sostener una sociedad basada en el simple disfrute y en el confort porque a la postre terminaría volviéndose contra ella. Ortega apostará por la recuperación del liberalismo, como cultura, como forma de vida en continua creación para evitar el desarrollo de tensiones y luchas entre los

10 Cf. J. Ortega y Gasset, “QQué es filosofía?” en Obras Completas. Tomo VIII (1926-1932). Obra póstuma. Madrid, Taurus, 2008, Lección X, pp. 359-374

11 Cf. J. Marías, "Introducción a La Rebelión de las masas”, Cuenta y razón 130, 2003, pp. 141-156.

12 Cf. P. Cerezo, "De la melancolia liberal al ethos liberal (En torno a La Rebelión de las masas de José Ortega y Gasset)", Endoxa: Series Filosóficas 12-1, 2000, pp. 313-340.

13 J. Ortega y Gasset, "La rebelión de las masas", en Obras completas. Tomo IV. Madrid, Alianza Editorial, Revista de Occidente, 1983, p. 121. Compilado recientemente en J. Ortega y Gasset, Obras Completas. Tomo IV (19261931). Madrid, Taurus, 2017, pp. 349-540. Citaremos los escritos no póstumos de Ortega comprendidos entre 1926 y 1931 por la edición de Alianza.

14 Cf. P. Cerezo, De la melancolía liberal al ethos liberal (En torno a La Rebelión de las masas de José Ortega y Gasset), op. cit., p. 320. 
diversos elementos de la nación. Hablará de la recuperación de una elite rectora y de la democracia como una posibilidad de organizar un proyecto político de largo alcance $^{15}$. Así, concreta el propio Ortega:

La democracia liberal fundada en la creación técnica es el tipo superior de vida pública hasta ahora conocido; segunda, que ese tipo de vida no será el mejor imaginable, pero el que imaginemos mejor tendrá que conservar lo esencial de aquellos principios; tercera, que es suicida todo retorno a formas de vida inferiores a las del siglo XIX'16.

\section{Ortega y la recepción del fascismo}

Sin embargo, pese al gesto liberal orteguiano, el primitivismo del hombre-masa, como también percibió Zambrano, declinará, bajo su punto de vista, pronto en barbarie. Frente a un liberalismo exhausto, a comienzos de los 30, el desarrollo de los estados totalitarios europeos parecía imparable. En este contexto, las principales plumas de la intelectualidad española de manera vertiginosa se podrán a escribir sobre los grandes movimientos de masas que acaecen en Rusia, Alemania e Italia. Las minorías gobernantes se vieron obligadas a poner sus ojos en lo que estaba pasando más allá de las fronteras españolas con el intento de avistar alguna posibilidad para el moribundo régimen español ${ }^{17}$. El propio Primo de Rivera, al regreso de un viaje a Italia en noviembre de 1923, comentó que debía mucho a la influencia de Mussolini1 ${ }^{18}$. En

15 Hay que subrayar que para el Ortega de La Rebelión de las Masas, la democracia liberal, entendida como democracia representativa, es el único sistema aceptable. Sin embargo, alertando de los riesgos del acceso de las masas al "imperio de lo político" va a contraponer la "vieja democracia" frente a la "hiperdemocracia", dando por sentado que esta última supone la culminación de la rebelión de las masas. En última instancia, vino a decir que la hiperdemocracia en la medida en que podía caer en la tiranía de la mayoría abría el camino a los totalitarismos. Cf. J. Ortega y Gasset, "Goethe desde dentro", en Obras completas. Tomo IV. Madrid, Alianza Editorial, Revista de Occidente, 1983, p. 379. Esta posición es muy distinta de la que Ortega planteó en Vieja y nueva política (1914), en donde limitó su análisis socialista previo, para hablar de un cierto liberalismo nacional bajo una estructura que compaginara la cultura con una vida auténtica. Para este tema resulta preciso consultar: I. Sánchez Cámara; "Liberalismo y democracia en Ortega", en P. Cerezo, Ortega en perspectiva, Madrid, Instituto de España, 2002, pp. 113-145, aquí 125.

16 J. Ortega y Gasset, La rebelión de las masas, op. cit., pp. 173-174.

17 Sobre las tensiones entre nacionalismo y modernidad resulta adecuado consultar: E. González Calleja, La España de Primo de Rivera. La modernización autoritaria 1923-1930, Madrid, Alianza Editorial, 1995. Así mismo, resulta crucial la discusión historiografía y el análisis bibliográfico en torno a la Dictadura de Primo, en concreto sobre la comparación entere los procesos de desarrollo, modernización y movilización planteados en España con respecto a otro países y los procesos de incorporación de nuevos sectores sociales a la vida política, propuestos en: C. González, Anales de Historia Contemporánea 16, 2000, pp. 337-408.

18 M. Peloille, Fascismo en ciernes. España 1922-1930. Textos Recuperados, Toulouse-Le Mirail, Presses Universitaires du Mirail, 2005, p. 118. La bibliografía sobre la influencia entre regímenes es enorme. En un texto ya clásico, Shlomo Ben Ami ha planteado precisamente la relación entre los regímenes ibéricos y el italiano en su interpretación nacionalista y de lucha contra el liberalismo: "La dictaduras de los años veinte", en M. Cabrera, S. Juliá y P. M. Aceña (comps.). Europa en Crisis 1919-1939, Madrid, Ed. Pablo Iglesias, 1991.Veáse también S. Sueiro Seoane, "La influencia de Mussolini y su régimen en la dictadura de Primo de Rivera", Proserpina: revista de la Universidad de Educación a Distancia 1, 1984, pp. 35-50. Por su parte, Tusell y Queipo de Llano han considerado que la Dictadura de Primo puede interpretarse bajo una tipología bastante diferente de la propiamente fascista. Cfr. J. Tusell y G. Queipo de Llano, "La Dictadura de Primo de Rivera como régimen político. Un intento de interpretación”, Cuadernos del ICE 10, 1979, pp. 37-64. 
verdad, de lo que se trataba era de poner en marcha un plan de modernización para el cual, según las elites políticas, la dictadura estaba incapacitada. Además, la radicalización del proletariado, como consecuencia de la revolución de 1917, hacía pensar a algunos intelectuales, como a Maeztu, que la única salida viable pasaba por la guerra civil $^{19}$. Según el tradicionalista, la única posibilidad para la monarquía requería de un katechon contrarrevolucionario. Para todo ellos, la necesidad que imperaba era la de fortalecer al Estado frente a la Revolución o dicho de otra manera, toda alternativa de continuidad del régimen pasaba por la Contrarrevolución “típicamente" española. De tal modo que todos los sectores políticos de la derecha simpatizarían de una manera u otra con el nuevo régimen italiano ${ }^{20}$.

Con continuidad en la prensa de la derecha española, sobre todo en La Nación, el órgano oficial de la Dictadura, a través de las voces de d'Ors o del mismo Maeztu se ensalzaban los logros del fascismo ${ }^{21}$. El periodista habló precisamente de la urgencia de: "Un partido del centro que, si se da cuenta de su altísima misión hispánica, puede en muy poco tiempo adueñarse de la península Ibérica, como el fascismo italiano se ha apoderado de la península hermana"22. Para el vasco, toda posibilidad de futuro para España pasaba por la creación de un partido interclasista que integrara la vivacidad del capital, las fuerzas del conservadurismo y la idea de unidad nacional. Este será el ambiente en el que surja el partido Acción Española ${ }^{23}$. Sin embargo, este partido, que Morodo calificó en su momento de "prefascista" 24 , pese a su propósito de mimesis del movimiento italiano, se diferencia de aquel en que encuentra su especificidad en la propia historia política española. Su concepción contrarrevolucionaria está más próxima a las guerras carlistas que a la Marcha sobre Roma ${ }^{25}$. De igual modo, el pretendido estado corporativo instaurado por Primo de Rivera tendrá más que ver con la tendencia social católica del corporativismo español que con la novedosa cámara sindical italiana ${ }^{26}$. Maeztu y los hombres de Acción Española intentaron configurar en base al mito de lo nacional una katechon contrarrevolucionario en la estela de Donoso Cortés frente al mito de la revolución, luego de la Republica, muy alejado ideológicamente de los modernos movimientos de masas italianos y alemanes.

No obstante, con la excepción de algunos escritores españoles, como el más tarde falangista Sánchez Mazas quien veía en Maura el Mussolini español, nadie pensaba

19 J. L Villacañas, Ramiro de Maeztu y el ideal de la burguesía española, Madrid, Espasa-Calpe, 2000, p. 250.

20 G. Queipo de Llano, Los intelectuales y la dictadura de Primo de Rivera, Madrid, Alianza Universidad, 1988, p. 476.

21 Cf. A. Révész, "La muerte del parlamentarismo en Italia”, Abc, 25 de noviembre de 1927, pp. 9-10.

22 R. de Maeztu, Liquidación de la monarquía parlamentaria, Madrid, Editora Nacional, 1957, p. 142.

23 J. L. Villacañas Berlanga, Ramiro de Maeztu y el ideal de la burguesía española, op. cit., p. 251. Cf. P.C. González Cuevas, Acción española. Teología política y nacionalismo autoritario en España (1913-1936), Madrid, Tecnos, 1998; Pensamiento conservador español. Ideas políticas de Maeztu, Maurras y Schmitt, Madrid, Biblioteca Nueva, 2002.

24 R. Morodo, Los orígenes ideológicos del franquismo: Acción Española, Madrid, Alianza Universidad, 1985.

25 Coíncidimos con J. L. Villacañas cuando asegura que la presentación de Acción Española como movimiento afín al fascismo es "epidérmica y voluntarista" (J. L. Villacañas, Ramiro de Maeztu y el ideal de la burguesía española, op. cit., p. 252). El verdadero fascismo, en sentido laxo del termino, que implicará una rupturá con la tradición conservadora española, comenzará a intituirse como tal a partir del surgimiento de en 1931 de La Conquista del Estado.

26 C. González Cuevas, Historias de las derechas españolas, Madrid, Biblioteca Nueva, 2000, p. 278; M. A. Perfecto García, "Panorama de la idea corporativa en Europa hasta los años 30 del siglo XX”, Studia Histórica. Historia contemporánea Vol. II, 4, 1984, pp. 157-168. 
en la aplicación directa del modelo italiano para España ${ }^{27}$. Tal y como ha señalado José Luis Villacañas, "nuestra recepción del fascismo fue sintomatológica"28. Para estos intelectuales, el análisis sobre el fenómeno italiano servía para presagiar las posibles vías a recorrer de los futuros procesos de transformación que podría experimentar la realidad social española. Este sería el planteamiento que dominará las creaciones intelectuales desde 1924 a 1930. El fascismo se planteó en aquellas como el modelo regulador y director del proceso modernizador español. Aquí es precisamente donde toman fuerza los trabajos sobre el fascismo como fenómeno que desarrollarían Cambó ${ }^{29}$, Chabás ${ }^{30}$ y el propio Ortega.

El filósofo madrileño consagró diversos textos al movimiento fascista, "el síntoma más grave de toda la vida política contemporánea". En 1925, escribió su primer artículo dedicado explícitamente al fascismo ${ }^{31}$. El trabajo era una respuesta a la "sugestiva nota" publicada en El Sol, bajo el título de "La rebelión de las camisas" de Corpus Barga ${ }^{32}$. En ese trabajo Ortega también se hacía eco de la publicación de Francésc Cambó en torno al movimiento italiano. El filósofo en contra del autor catalán buscó captar la esencia del fascismo más allá de sus contradicciones (su carácter ambivalente de ser autoritario y revolucionario) ${ }^{33}$. Para Ortega, el fascismo se presentó como un fenómeno histórico cuya naturaleza estaba fuera de él. Incluso, "detrás del él", dice el filósofo. Este "estar detrás" sería el resultado del fracaso de las viejas políticas liberales y democráticas a las que el fascismo combatía. Lo rotundo del éxito del fenómeno era justamente el fracaso de la política liberal. En su opinión, no se podía estar a la altura de los tiempos si se seguía trabajando con teorías políticos liberales del s. XIX. Ortega sentenciará que "fascismo y cesarismo tienen, como supuesto común, el previo desprestigio de las instituciones establecidas" ${ }^{\prime 3}$. Lo esencial del fascismo era la ilegitimidad de la forma con la que se relacionaba con el exterior. A su modo de ver, "el fascismo no sólo se adueña del poder ilegítimamente, sino que, una vez establecido en él, lo ejerce también con ilegitimidad". Para Ortega, la fuente de esta ilegitimidad es la violencia con la que accede al poder que se perpetúa en el modo de ejercerlo y que lo diferencia de los otros regímenes revolucionarios, que establecen derecho en el mismo momento revolucionario. El gobierno soviético usaría, a su parecer, la violencia para fundar derecho, pero no adquiere de aquella su derecho. El fascismo por el contrario hace de la violencia su derecho, como antes hemos podido comprobar. No se preocupará de dar fundamentos jurídicos a su poder, ni consagrarlos en teoría política alguna porque se sustenta sobre la base de la

27 R. Sánchez Mazas, "El directorio militar español a la luz romana”, Abc, 10 de octubre de 1923, pp. 7-8 y "Maura, el fascismo y la ilusión nacional", Abc, 25 de diciembre de 1925, pp. 1-2. Cf. G. Queipo de Llano, op. cit., p. 477 y ss.

28 J.L. Villacañas, "Sobre la temprana recepción española del fascismo. Un ensayo sobre el contexto de Italia fascista de Juan Chabás", en Biblioteca Virtual Saavedra Fajardo < saavedrafajardo.org>.

29 F. Cambò, En torn del feixisme italià, Barcelona, Catalana, S. A., 1925.

30 J. Chabás, Italia Fascista (politica y cultura), Barcelona, Mentora, 1928.

31 J. Ortega y Gasset, "Sobre el fascismo", en Obras Completas. Tomo II (1916). Madrid, Taurus, 2004, pp. 808125 .

32 C. Barga, "La rebelión de la camisas", El Sol, 11 de febrero de 1925. Sobre la recepción del fascismo entre la intelectualidad española véase: P. Aubert, "El papel de los intelectuales" en C. Serrano y S. Salaün (eds.), Los felices años veinte. España, crisis y modernidad, Madrid, Marcial Pons, pp. 113-134.

33 "El fascismo tiene un cariz enigmático, porque aparecen en él los contenidos más opuestos. Afirma el autoritarismo, y a la vez organiza la rebelión" (J. Ortega y Gasset, Sobre el fascismo, op. cit., p. 608).

34 J. Ortega y Gasset, Sobre el fascismo, op. cit., p. 611. 
violencia desnuda. Esta es la novedad del nuevo fenómeno de masas, según Ortega. Los demás rasgos serían caracterizaciones propias del siglo XIX que han perpetuado en el s. XX. Sin embargo, resulta complicado para una persona del s. XXI, después de todo lo que ha acontecido, aceptar que pueda darse en una sociedad de masas una dominación basada en el simple hecho de la mera coacción o de la violencia. A nuestro parecer, es necesario que exista un vínculo carismático entre el líder ya sea Duce, Caudillo o Führer, que sea capaz de estructurar con la suficiente cohesión la sujeción que se da entre el mando y la obediencia. Todo esto Ortega lo pasará por alto $^{35}$. De hecho, para Ortega, "la fuerza de las camisas fascistas, consiste, más bien, en el escepticismo de liberales y demócratas. La ilegitimidad extraña que practica el fascismo sería, pura y simplemente, un signo de que la sociedad entera se halla exenta de normas legítimas"36. De este modo, para Ortega, la fuerza del fascismo se basaría en la incapacidad que han tenido las instituciones liberales para legitimarse ante las masas. A punto de concluir el texto dice Ortega: "hoy no existe en las naciones continentales ninguna forma de legitimidad que satisfaga a los espíritus". Aunque el filósofo español se olvida de Max Weber, lo que está solicitando Ortega es una nueva forma de carisma que sea a la vez compatible con las viejas formas liberales. En suma, está solicitando un político fuerte para un ejecutivo fuerte, pero que tenga un sostén liberal-democrático. Él sabía de sobra que no se podía mantener el poder sin el apoyo de las mayorías ${ }^{37}$. En última instancia, Ortega estaba realizando una construcción teórica que no estaba capacitado para entregar a la sociedad española y que tuvo con el paso del tiempo sus perversas derivaciones. Pronto sus discípulos más radicales iban a comprender el papel tan importante que el carisma iba a jugar en el período político que con el año 30 se abría, así como el moderno uso de los medios de propaganda y la utilización de los mitos políticos para la consecución del mismo. Sin embargo, a mi modo de ver, su análisis de fascismo es inexacto y escapaba a sus posibilidades. Ortega no estaba en condiciones de captar la fuerza que el carisma ostenta para establecer una legitimidad basada en resortes afectivos de carácter nacional. Por ello, el fascismo, para el filósofo madrileño, no tenía futuro. Algo que con cierta ambigüedad podríamos decir ahora, pero que es difícil de aseverar en aquel contexto.

\section{El liberalismo como puerta de salida a la Restauración}

Sin ninguna duda, los jóvenes vinculados a las empresas de Ortega habían leído el texto del maestro sobre el fascismo. El liberalismo se planteaba como la única posibilidad para dejar atrás la Restauración pero lo podría ser en la medida en que se asentase sobre bases exclusivamente democráticas. Se trataría de dirigir a las masas y no de subyugarlas. En un texto en el diario El liberal publicado en 1928, Zambrano señaló que el ideal de toda política debía estar guiado por "una libertad

35 Sobre la validez del diagnóstico orteguiano y su contraposición al weberiano véase el trabajo de J.L Villacañas sobre Juan Chabás en BSF. http://www.saavedrafajardo.org/archivos/respublica/hispana/DOC0007-JVB.pdf. (Consulta: 08-12-2018).

36 J. Ortega y Gasset, Sobre el fascismo, op. cit., p. 614

$37 \quad$ Ibidem. p. 612. 
esencialmente democrática" ${ }^{38}$. Bajo la estela de Ortega, a quien inmediatamente se reconocerá como maestro de la nueva generación ${ }^{39}$, la filósofa planteó una política que recuperara el "pulso" de la vida española y que se pusiera al servicio de los altos valores morales y culturales, al servicio del espíritu, en vez de pretender apresarlo. Con la tarea de acometer esta empresa, y con evidentes ecos de la Liga de Educación Política de 1914, nacía en junio de 1928 la Liga de Educación Social. La plataforma surgía con el fin de intervención en la vida política española de una nueva generación que saltaba briosamente a la esfera pública. Pronto intentó alinearse con la generación de "los maduros", la de los Jiménez de Asúa, Azaña, Marañón, Indalecio Prieto, Pérez de Ayala, etc., asumiendo como presupuestos propios y con compromiso el ideario político regeneracionista de Ortega ${ }^{40}$. Sin embargo, frente al liberalismo orteguiano, la Liga tendrá un marcado talante social emanado del posicionamiento ideológico de sus miembros en su mayoría próximos al PSOE y a la Institución Libre de Enseñanza. La propia Zambrano participó desde 1931 en el proyecto educativo de las Misiones Pedagógicas de Manuel B. Cossío ${ }^{41}$. Lo que nos lleva a advertir que el regeneracionismo krausista de la I.L.E influirá de manera determinante en los años de formación de la filósofa malagueña ${ }^{42}$. Sus trabajos iniciales se moverán en la atmósfera de reforma cultural que el institucionalismo emanaba. Tanto para Zambrano como para los institucionalistas, los cambios sociales no se deben efectuar de una manera precipitada o revolucionaria sino de forma gradual, pacífica y evolutiva, única vía, dicen los krausistas, por la que es posible reformar y transformar los individuos y los organismos sociales ${ }^{43}$. Además, el institucionalismo promoverá la defensa de la persona individual, que será considerada sagrada y que debe ser respetada como tal ${ }^{44}$. El personalismo de Zambrano también hallará aquí sus primeros fundamentos. Además, los desarrollos intelectuales del krausismo durante las primeras décadas del siglo pasado derivarán a un tenue planteamiento liberal con matices sociales. Bajo su punto de vista, la reforma ética del individuo implicaría la construcción de una sociedad mejor. Para la propia Zambrano, la reforma de España pasaba, no sólo por la regeneración del entendimiento, sino también por la moral. De este modo, el institucionalismo se presentará como el intento de fundamentar una sociedad armónica por medio de la reforma educativa. En este marco de reformismo

38 M. Zambrano "Hemos hecho alusión”, El Liberal, 26 de julio de 1928. Cf. M. Zambrano, La deshumanización del arte, Estudio de J. F. Ortega Muñoz, Sevilla, Fundación María Zambrano, U.G.T Andalucía, 2002, pp. 15-18.

39 M. Zambrano, "Delirio y destino. Los veinte años de una española" en M. Zambrano, Obras Completas VI, Barcelona, Galaxia Gutenberg, 2013 p. 868.

40 Cf. M. Zambrano, Delirio y destino. Los veinte años de una española, op. cit., p. 869.

41 A. Bundgård, Un compromiso apasionado. María Zambrano: una intelectual al servicio del pueblo (19281939), op. cit., pp. 121-126; A.I. Salguero Robles, "El pensamiento y el compromiso político de María Zambrano", Actas II Congreso Internacional sobre la vida y obrade María Zambrano (Vélez-Málaga, 1994), Vélez, Fundación María Zambrano, 1998, pp. 699-718; A. Viñao Frango, "Las Misiones Pedagógicas: entre lo popular y lo culto" en J.L. Casas Sánchez y F. Durán Alcalá, 1931-1936, De la República democrática a la sublevación militar: [Actas del] IV Congreso sobre Republicanismo, Córdoba, Universidad de Córdoba, 2009, pp. 177-192; J. Bécarud y E. López Campillo, Los intelectuales españoles durante la II República, Madrid, Siglo XX Editorial, 1978, pp. 38-40.

42 Cf. A. Bundgård, op. cit., pp. 98 y ss.

43 Sobre la filosofía social de krausismo español y la reforma social e individual que propone, entre otros: E. Díaz, La filosofía social del krausismo español, Madrid, Debate, 1989; E. Díaz, De la Institución a la Constitución. Política y cultura en la España del s. XX, Madrid, Trotta, 2009, p. 43 y ss.

44 F. Giner de los Ríos, La persona social, 2 tomos, Madrid, Victoriano Suárez, 1899. 
social, se situarán sus relaciones con el socialismo de Julián Besteiro, Fernando de los Ríos, Rodolfo Llopis y tantos otros con los que la joven Zambrano entrará en contacto en sus incipientes acciones políticas.

En el mes de abril de 1929, cuando ya se avista el fin inminente de la Dictadura un grupo de jóvenes escritores discípulos de Ortega exigirían la politización de la intelectualidad dentro de un nuevo "horizonte de libertad". En el grupo figuran entre otros, José Díaz Fernández, María Zambrano, Fernando Vela, Federico García Lorca, Francisco Ayala, etc. ${ }^{45}$ No cabe duda de que aquellos jóvenes habían leído el trabajo sobre el fascismo. En la carta se aseveraba la orientación y magistratura filosófica y política de Ortega sobre ellos, a la vez que se remarcaba el carácter liberal del grupo y se afirmaba la aspiración a la formación de un partido fuerte de inspiración nacional. Todos están convencidos de que "por primera vez desde hace centurias va a ser posible un ensayo grande de reorganización nacional. Hasta lo malo ha sido bueno y, contra su voluntad, sirvió a la madurez en la coyuntura"46.

La respuesta de Ortega, poco alentadora, no sirvió para consolidar los esfuerzos de los jóvenes. Ortega habló allí de "parasitismo negativo" y expuso sus deseos de revolución nacional. Pero en ningún momento hubo un apoyo desbocado al joven grupo. La nueva generación que pretendía intervenir en la vida política de España se encontró sin el sostén de su maestro. Sin embargo, la actividad del joven grupo se apresura. Al año siguiente, José Díaz sacará a la luz El nuevo romanticismo y la propia Zambrano su Nuevo liberalismo (en la cubierta, Horizonte del liberalismo), ambos de clara raigambre orteguiana. También el filósofo madrileño publicaba su conocidísimo La rebelión de las masas, cuyos textos habían ido viendo la luz en la prensa diaria. El gesto y la pretensión, a raíz de las circunstancias, estaban claros: el liberalismo decimonónico era ineficaz ante la situación de rebelión de las masas propia del siglo XX, y se presentaba insuficiente ante la propia circunstancia española. La Dictadura se mostraba incapaz para llevar a cabo un proceso de regeneración nacional. Para todos ellos, era necesario volver a la vieja idea de Ortega de la "nacionalización" planteada en el 14. A sus ojos, el momento era similar a aquél en el que vio la luz Vieja y nueva política y las Meditaciones del Quijote. Una nueva generación se presentaba a la vida pública española y tomaba a Ortega como mentor intelectual con el mismo propósito de aquel año: de liquidar los usos políticos vigentes en la España de la Restauración ${ }^{47}$. Todo pasaba ineludiblemente por un nuevo liberalismo capaz de poner en marcha las energías nacionales del país. Así, todos aquellos trabajos estaban dominados por el planteamiento de una revolución nacional positiva donde una minoría rectora orientara a las masas.

45 La carta está presente en J. Ortega y Gasset, "Señor Don...” en Obras Completas. Tomo VIII (1926-1932). Madrid, Taurus, 2008, pp. 173-176.

46 J. Ortega y Gasset, Señor Don..., op. cit., p. 174. Sobre la politización de los intelectuales en los años 30, entre el abundante material, es recomendable consultar, por la labor de síntesis acometida, el trabajo de: P. Aubert, "El papel de los intelectuales", en C. Serrano y S. Salaün (eds), Los felices años veinte. España, crisis y modernidad, Barcelona, Marcial Pons, 2006, pp. 113-134.

47 Cf. P. Cerezo, "Experimentos de nueva España", Introducción a J. Ortega y Gasset, Vieja y nueva política, Madrid, Biblioteca Nueva, 2002, pp. 11-88. 


\section{Tras la Dictadura: horizontes de libertad}

Bajo esta perspectiva vio la luz Horizonte del liberalismo de María Zambrano. Un texto que, con todos sus límites, se esbozará como programa político frente a la Dictadura, proponiendo el liberalismo como doctrina salvadora de las circunstancias de su tiempo ${ }^{48}$. La obra sería publicada en Madrid en septiembre de 1930, en la colección de motivado título "Nueva Generación" de la Editorial Morata y abriría sus páginas con las siguientes preguntas: “¿Qué es política? ¿De qué raíz emana?¿Qué significa la política frente a la vida: la sigue o la detiene? [...] ¿Qué valor puede tener la política en los momentos actuales?"49.

Zambrano asumía allí el diagnóstico orteguiano que aseguraba, acertadamente, que con Primo de Rivera, España se había modernizado en todo, principalmente en lo referente a lo económico y a lo social. Al mismo tiempo, la Dictadura propició un desarrollo nunca visto en lo burocrático y en lo científico. No obstante, estos adelantos no se habían dado en la técnica constitucional democrática española. El pueblo seguía sin estar presente en las instituciones del Estado. Asimismo, Zambrano persistiría en el diagnóstico sobre España esbozado por Ortega en Vieja y nueva política para quien la Dictadura y la Monarquía eran la continuación moribunda de aquella "España oficial" de la Restauración incapaz de abarcar a los nuevos movimientos sociales y políticos, de incorporar a las "nacionalidades", de integrar a los intelectuales y que todavía seguía anclada en un pasado que aprisionaba a la otra España, la Vital. En esta coyuntura, la forma republicana se proyectaba para algunos sectores inteletuales como un horizonte, cada vez más cercano, por el que podía y debía correr la vida española. De modo que todo proyecto político que quisiera acometer la tarea de la nacionalización de España, pasaba a estas alturas por el cambio en la forma de gobierno. Esta sería la misión de la "nueva generación", al modo de ver de Zambrano: construir un proyecto de vitalización nacional desde políticas liberales, y por ende, democráticas. Se trataba de, por una vez, acometer adecuadamente la tarea de modernización de España, para poner al país a la altura de los tiempos. En este sentido, la política se constituía como voluntad de poder, como un proyecto de intervención en la circunstancia social y política; en última instancia, en la circunstancia vital, como había dictado Ortega en sus cursos. Para Zambrano, la transformación de la sociedad requería de grandes ideales. La juventud no podía conformarse con los hábitos heredados del pasado. Debía acometer la tarea de renovación de España mediante la reforma intelectual del pueblo español. Debía rehacer el proyecto orteguiano, que a la postre sólo pasaba por adscribirse a la más pura tradición liberal-democrática.

Para Zambrano, la política debía partir del no conformismo ${ }^{50}$. La juventud, a su modo de ver, no podía continuar haciendo política con los usos heredados de la Restauración. Eso hubiera significado dar la espalda a la vida, enterrar lo poco que quedaba de la España Vital. Cuando se protesta ante la realidad que existe, se tiene que exigir lo que debe ser, escribe. Se debía perseguir, por tanto, un Ideal: "Es, pues

48 Cf. L. de Llera, "María Zambrano y los años 30: horizontes de un nuevo liberalismo", Revista de Occidente 277, 2004, pp. 99-118. De Llera interpreta el primer libro de Zambrano como un esfuerzo valiente de concretar el proyecto orteguiano de 1923-30, desde un catolicismo próximo al manifestado en Cruz y raya por Bergamín. A nuestro modo de ver, en Horizonte del Liberalismo predomina una orientación institucionista.

49 M. Zambrano, "Horizonte del liberalismo" en M. Zambrano, Obras Completas I, Barcelona, Galaxia Gutenberg, 2015, p. 57.

50 M. Zambrano, Horizonte del liberalismo, op. cit., p. 58. 
un problema entre dos términos: un individuo que actúa y una vida que se ofrece como materia reformable" 51 . Sólo desde un liberalismo de grandes ideales, que uniera vida y Cultura, se fecundaría de nuevo la vida nacional. De este modo, Zambrano llamaba a los jóvenes a que acometieran la tarea de reforma nacional que abrían los acontemicientos políticos del año 30. La Dictadura y la Monarquía no habrían sido más que el "naufragio positivista, después de la disgregación producida por un científismo mediocre"52. Como vemos, Zambrano recupera a Nietzsche de la mano del vitalismo de Ortega. Se apropiaba del juicio sobre la crisis cultural de Europa dado por su maestro en El tema de nuestro tiempo y en ¿Qué es filosofía?, para plantear que el racionalismo europeo había subyugado la vida a la razón. El triunfo del positivismo, y con él, el de las masas, era el triunfo de los nuevos "bárbaros".

Urgen, por tanto, escribe Zambrano, "creadores del hombre", que puedan resolver los temas metafísicos del ser y la vida, del individuo y del mundo. Apresuran intelectuales y, a la vez, políticos, que amen la vida, y que no la apresen ${ }^{53}$. Zambrano clama la necesidad de unas elites nuevas que asuman con responsabilidad el encuentro con la vida. Sólo desde una razón que fuera integral, que enarbolara la vida como realidad radical o primera era posible salvar la circunstancia española de un sistema político que yacía muerto. Imitando el gesto orteguiano, llamaba así a su generación a convertirse en poder espiritual rector de la sociedad.

Igual que Ortega, su opción pasará por el liberalismo, que debía proporcionar el nuevo horizonte que la vida española recorriese. El liberalismo debía impedir la política fanática que se había dado en España y que, a su modo de ver, "ha llevado a cada uno reconocer no más que un individuo: el nuestro, rechazando toda diversidad" 54 . Se trataba de construir una nueva política capaz de cambiar las fuerzas vivas de los individuos, de formar a los hombres medios, de crear una nueva concepción de la vida española "heterodoxa". En última instancia, la cuestión fundamental era hacer que la vida volviera a correr, lo cual sólo podía realizarse en la medida en que fuera posible estructurar un sistema democrático, como Ortega había señalado en su texto sobre el fascismo, donde la Cultura confluyera con el vitalismo de la sociedad.

Llegado este momento, Zambrano apostará por una política revolucionaria, pero en la medida que acoge el diágnostico orteguiano, no lo llevará a cabo sin ciertas dudas. Sabe del terror de la precipitación, sabe que la revolución también puede dar paso a la reacción ${ }^{55}$. Para nuestra filósofa, una política de esencia revolucionaria no significa necesariamente una revolución. La revolución acogía el riesgo de levantar sólo violencia y, como dijo Ortega en el texto sobre el fascismo, perpetuarse eternamente mediante ella.

\section{Ibidem.}

52 Ibidem. En este sentido, en España, sueño y verdad María Zambrano comenta, sobre el tópico que en España no ha existido filosofía, que el libro de Menéndez Pelayo La Ciencia Española no es más que "la enumeración de nombres y de títulos [que] suena, casi una letanía, del espíritu español que se enumera a sí mismo, para afirmarse" (M. Zambrano, "España, sueño y verdad”, en M. Zambrano, Obras Completas III, Barcelona, Galaxia Gutenberg, 2011, p. 733-734).

53 "El comunismo ruso ama tanto la vida que, en ansia erótica, quiere apoderarse de ella y detenerla" (M. Zambrano, Horizonte del liberalismo, op. cit., p. 62).

54 Ibidem.

55 "La revolución es un procedimiento que tanto puede efectuarse para abrir paso a una política revolucionaria como a otra de la más hermética esencia conservadora" (M. Zambrano, Horizonte del liberalismo, op. cit., p. $71)$. 
Así, Zambrano aceptaba el dictámen orteguiano: las masas se han rebelado. Nunca en Europa se ha había contemplado un hecho tan terrible, jamás habían sido destruidos tantos cuerpos. Nunca se habían levantado tantos hombres contra otros en nombre de la clase o la nación. En ningún modo se habían dado tantos sacrificios. Frente al sacrificio, Zambrano planteará la idea de humanidad como única organización supraindividual que admite el liberal. Es suma de individuos en igualdad. Pero por qué el liberalismo fue incapaz, por qué se desvirtuó. Para Zambrano, con el racionalismo, y sobre todo con Kant fue con quien "se proclamó el hombre como rey de la vida" ${ }^{56}$. Con lo que la vida se fue apartando de la política y de la ética. De tal modo, argumenta, que en el individuo kantiano ningún individuo podía reconocerse. Lo que originó una moral del deber, ascética, fría y racional, una moral de élites. Así, el liberalismo rehusó del hombre verdadero. En pocas palabras, dejó al margen los problemas del vivir, creando una moral que cargaba y que asfixiaba al hombre contemporáneo De hecho, dice Zambrano, el liberalismo tiene dos padres, por un lado el racionalismo por otro el nominalismo escotista. Pero el racionalismo había eliminado este límite llevando al exceso de individuación. Y este era, el drama, el racionalismo había provocado la disgregación de la masa, como ya vio Ortega en su obra $^{57}$.

Por todo ello, la importancia de la cuestión social que aparece destacada al final del texto y de la que se desprenderá otra paradoja del liberalismo, según Zambrano. A su modo de ver, la economía liberal es incompatible con los Derechos del Hombre que fomentó el liberalismo. No era posible combinar, según nuestra autora, los derechos del hombre con las condiciones sociales de la época. Ésta es la gran crisis de Europa, desde Lisboa hasta los Urales. Para Zambrano, todo se había descompuesto. Los movimientos sociales no han sido integrados en la política, menos si cabe, en la economía, por las minorías. Por eso, la autora apremia a la construcción de una "nueva economía, un nuevo liberalismo, amplio y fecundo, y un estado social y cultural en el que se sienta solidaria la masa con el político, con el intelectual, con todo el que dirige" 58 . Es más, para la filósofa, resulta, incluso extraño, hablar entonces del liberalismo, si no hay un punto de equilibrio para la libertad dentro del sistema económico. Por ello, para conservar la cultura liberal era necesaria, en su opinión, una nueva estructura económica. Ortega, no dijo algo muy distinto en su "primer acto público" en la Conferencia-Manifiesto electoral a finales del mes de junio de 1931 cuando habló de la cuestión social:

Esa transformación social radical implica la transformación del capitalismo. Pero yo veo el cambio de manera distinta a la usual. Es preciso hacer constar de la manera más explícita que los revolucionarios españoles están algo anticuados. Repiten hoy lo que en todas partes se decía hace años, y no han querido aprovechar la experiencia que en los últimos tiempos han recogido los grandes revolucionarios de fuera, los que verdaderamente han hecho, o por lo menos, han iniciado, grandes subversiones sociales.

\footnotetext{
56 M. Zambrano, Horizonte del liberalismo, op. cit., p. 84.

57 "La perfección misma con que el siglo XIX ha dado una organización a ciertos órdenes de la vida es origen de que las masas beneficiarias no la consideren como organización, sino como naturaleza. Así se explica y define el absurdo estado de ánimo que esas masas revelan: no les preocupa más que su bienestar y al mismo tiempo son insolidarias de las causas de su bienestar" (J. Ortega y Gasset, La rebelión de las masas, op. cit.,. p. 179).

58 M. Zambrano, Horizonte del liberalismo, op. cit., p. 99.
} 
Y esta experiencia, esta averiguación, consiste sencillamente en que la reforma social del mundo las revoluciones de forma cruenta no sirven de nada, o sirven muy poco, y que lo que tienen que hacer el verdadero revolucionario es dejar de pronunciar vocablos retóricos y ponerse a estudiar Economía, porque a la postre se ha llegado a descubrir que es imposible mejorar decisivamente al obrero si no aumenta en gran proporción la riqueza pública. De esta forma tan inesperada, la revolución social se ha convertido en un gigantesco movimiento de construcción económica. [...] Hoy, la única revolución auténtica es la de la técnica de la construcción económica, la del orden fecundo en la sociedad organizada en un cuerpo de trabajadores ${ }^{59}$.

Para algunos autores ${ }^{60}$, el pequeño trabajo de Zambrano no puede ser considerado una propuesta concreta de alternativa política, ya que se trataría más bien de una reflexión subjetiva sobre el concepto general de Política y sobre las causas posibles de la crisis española y/o europea Bajo nuestra mirada, resulta todo lo contrario. Zambrano va a plantear allí un liberalismo de corte social junto a una concepción del hombre próxima a lo religioso ${ }^{61}$ que posee ecos del racionalismo armónico del krausismo. De hecho, dirá Sanz del Río: “el racionalismo armónico profesa en religión y aspira a realizar la unión viva de la Humanidad y del hombre en ella con Dios como ser supremo"62. La idea de re-ligarse con Dios estará siempre presente en el resto de su obra. Por todo ello, se trata de un documento de primera importancia para entender la génesis y el desarrollo del pensamiento político de Zambrano ${ }^{63}$. Precisamente, el silenciamiento por parte de la autora a su "librillo" que encontramos a lo largo de toda su carrera hace que su análisis sea fundamental para comprender su decurso. Que ni siquiera haya referencias en sus textos más autobiográficos es una manifestación clara de la fractura que existe entre los trabajos anteriores al exilio y los escritos durante su experiencia. El "librillo" está escrito de manera "precipitada"64 precisamente porque pretende ofrecer una propuesta ante la situación que le sobreviene, y que se le impone. Es una clara apuesta, bajo la estela del proyecto orteguiano de vertebrar España, por salvar la circunstancia mediante un proceso de nacionalización que sólo el liberalismo podía desarrollar. Sin embargo, el planteamiento regeneracionista de Zambrano se aleja del liberalismo orteguiano para caer en uno krausista-socialista que plantea una concepción organicista de la sociedad, superadora de las luchas de clases. Dicho de otra manera, Zambrano tiene en mente un proyecto nacionalizador en cual la sociedad es vista como una conjunción armónica de asociaciones diversas y de individuos. Hablará de la solución de la cuestión social, pero sólo será posible en la medida que "la aristocracia espiritual" lleve a cabo un proceso de reforma ética

59 J. Ortega y Gasset, "Por una democracia española", en V. M. Arbeloa y M. de Santiago (Eds.), Intelectuales ante la Segunda República española, Salamanca, Ediciones Almar, 1981, pp. 237-238.

60 A. Bundgård, op. cit., p. 105

61 También Ana Bundgård a raíz de la lectura de las Cartas de la Pièce de Zambrano con Agustín Andreu ha hablado del liberalismo de Zambrano como "una propuesta de recuperación de la vinculación del hombre con lo espiritual, perdida según ella a consecuencia del racionalismo" (A. Bundgård, op. cit., pp. 128-129). Bajo esta posición, habría una vinculación entre los escritos anteriores al exilio y los restantes en la existencia de una continuidad en el tratamiento del "orbe religioso" de Zambrano.

${ }^{62}$ Citado en E. Díaz, De la Institución a la Constitución. Política y cultura en la España del s. XX, op. cit., p. 35.

63 J. Moreno Sanz, "La política desde su envés histórico-vital: Historia trágica de la esperanza y sus utopías", Introducción a M. Zambrano, Horizonte del liberalismo, Madrid, Ediciones Morata, 1996, pp. 9-195, aquí 163.

64 Ibidem. 
de los individuos, no considerando la posibilidad ni la necesidad de un cambio sustancial en el orden social y económico.

\section{La puesta en marcha de un partido algo más que liberal}

En enero de 1930 caerá la dictadura de Primo de Rivera y Alfonso XIII nombrará presidente de Gobierno a Dámaso Berenguer. El Gobierno Berenguer duró tan sólo catorce días. Le seguiría el Almirante Aznar. Los movimientos políticos y sociales descontentos con el inmovilismo de aquellos gobiernos, pidieron la creación de Cortes Constituyentes. El país parecía respirar un ambiente de renovación exigible que se revelaba incompatible con la Monarquía. Ante esta realidad, los intelectuales españoles se fraccionaron entre aquellos que apoyaron al Directorio y aquellos que se mostraron contrarios a éste.

El 11 de febrero de 1930, pocos días después de que Ortega publicase en El Sol el artículo con el conocido título: "Organización de la decencia nacional”, Zambrano escribía al filósofo madrileño en términos que han sido tachados de osadía ${ }^{65}$ :

La primera exigencia indudable -dice allí Zambrano- en la dignificación y nacionalización española pasa por el advenimiento del régimen republicano y nadie hay tan ingenuo y poco exigente que lo espere todo de él, pero la monarquía consumió y sacrificó a su sostenimiento todo lo que podía haber sido savia, vida de la nación y es, además, la primera de las instituciones desnacionalizadas aquí y en todas partes $^{66}$.

En aquel artículo Ortega había señalado que la Dictadura no era más que la continuidad de la Restauración y que, por lo tanto, su crisis era la crisis final de aquel período. Para Ortega, Primo de Rivera había sido el "enfant terrible" del Antiguo Régimen, el último garante de su persistencia. Para Zambrano, Primo de Rivera representaba "a esa España que todo lo reduce a lo doméstico" ${ }^{67}$. Su presencia significa la continuidad de la disgregación del s. XIX. Asimismo, Ortega, planteó la necesidad de volver a una "normalidad legal". En su opinión, la Dictadura carecía de legitimidad porque el ejecutivo no representaba y no defendía los intereses de la nación, porque había contribuido a crear una fisura insalvable entre el gobierno y el parlamento ${ }^{68}$. Dice Ortega tajantemente: "Salvo unos cuantos grupos próximos al Estado, los españoles no han podido vivir vida pública". Los argumentos son próximos a los de Vieja y nueva política ${ }^{6}$ : la necesidad de congregar a todo el pueblo

65 Cf. J. F. Ortega Muñoz, Biografía de Maria Zambrano, Málaga, Editorial Arguval, 2006, p. 43.

66 M. Zambrano, "Tres cartas de juventud a Ortega y Gasset", Revista de Occidente 120, 1991, p. 14.

67 M. Zambrano, Delirio y destino. Los veinte años de una española, op. cit., p. 996.

68 Sobre la idea de nación en Ortega véase: X. Bastida Freixedo, "La búsqueda del Grial. La Teoría de la nación en Ortega", Revista de Estudios Políticos 96, 1997, pp. 43-76.

69 "Tuve la audacia juvenil de dar una conferencia sobre «Vieja y nueva política», que casi tolera hoy ser releída, donde se anuncia todo lo que después ha acontecido. En esa conferencia resumía yo el programa de lo que sustancialmente hay que hacer en la vida política de España, dentro de esta expresión: hay que nacionalizar todas las instituciones del Estado, porque todas están desnacionalizadas" (J. Ortega y Gasset, "Organización de la decencia nacional", en Obras Completas, Tomo XI. Madrid, Alianza Editorial, Revista de Occidente, 1983, 
bajo una misma causa y la idea de aglutinar a todas las minorías intelectuales en un mismo partido nacional interclasista:

la decencia de la vida pública española consiste en imponer a todos los españoles la voluntad de convivir unos con otros, sean quienes sean unos y otros [...] por tanto respetar la vida pública del enemigo, de no escatimarle, ni discutirle ni sofisticarle sus derechos de español, sea el que fuere: el fraile al ateo y el ateo al fraile, el militar al civil y el civil al militar, el patrono al obrero y el obrero al patrono. Pero mientras el obispo o el militar aspiren en el fondo de su alma, no solo a vencerme, deseo respetable, sino a suprimirme de la vida pública o yo aspire a lo mismo con respecto a ellos, nuestra existencia nacional ni será decente ni será nacional ${ }^{70}$.

No obstante, las críticas a la Dictadura de Ortega no parecerán suficientemente explicitas a Zambrano. De hecho, la filósofa le recriminó "su tangencia en este momento" y que "el artículo no esté a su habitual altura", hasta el punto de decir que nunca se lo hubiera adjudicado a Ortega. A su modo de ver, se acertaba con el diagnóstico pero no realizaba en ningún caso un pronóstico. No había un proyecto para "organizar la decencia nacional". La carta de Zambrano será más bien un "manifiesto" del joven grupo que se encomendaba a Ortega con la intención de ampararlo como líder intelectual del proyecto. Ante el tema de su tiempo, ante la rebelión de las masas, el grupo de orteguianos, consideraba que la única salida posible pasaba por un liberalismo de corte nacional, de quien "Don José" es "conservador", pero a la vez le requiere que sea "revolucionario", es decir que apueste por el derrumbamiento de lo que queda de Restauración, del Antiguo Régimen. La liga de jóvenes orteguianos de izquierdas lo designa y le exige que defienda su proyecto. Al mismo tiempo pretenden trasmitir al maestro el deseo de toda una generación ${ }^{71}$ : la única posibilidad para la organización nacional pasa por la República, pues ésta es la aspiración y la tarea de nacionalización que la nueva generación quiera dirigir. La discípula es en este sentido radical: "cualquier política que ahora no intente derrumbar la Monarquía tendrá en la historia la significación de haber sido su puntal, su arbotante, en el momento justo que iba a derrumbarse"72. Zambrano reclamará a Ortega de manera inexcusable el compromiso con la causa. La primera nacionalización debe ser la del Estado y ésta es sólo posible mediante el advenimiento de régimen republicano.

El 3 de noviembre de 1930, Zambrano redactó una segunda carta a mano a su maestro en dos cuartillas de papel-tela blanco. El tono es totalmente distinto de aquella primera. La posición de distancia personal y política está marcada desde las primeras líneas del texto. Zambrano le remite a Ortega las notas que han aparecido insertas en la página 5 de El Socialista de Madrid el día anterior firmadas por Pablo A. Cobos. La información ocupó en el diario una larga columna y en ella se aclama la aparición de Horizonte del liberalismo ${ }^{73}$. La recensión de Cobos sirve de índice,

p. 271. Editado en tiempo reciente en J. Ortega y Gasset, Obras Completas. Tomo IV (1926-1931). Madrid, Taurus, 2017, pp. 755-759).

70 J. Ortega y Gasset, Organización de la decencia nacional, op. cit., pp. 272-273.

71 M. Mora, "María Zambrano: Tres cartas de juventud a Ortega y Gasset", Revista de Occidente 120, Mayo, 1991, pp. 7-26. Cf. A. Bundgård, op. cit., p. 151 y ss.

72 M. Zambrano, Tres cartas de juventud a Ortega y Gasset, op. cit., p. 14.

73 El comentario de Pablo de A. Cobos aparece recogido en la edición de las tres cartas de Zambrano a Ortega de M. Mora. Cf. M. Zambrano, Tres cartas de juventud a Ortega y Gasset, op. cit., p. 17 y ss. 
que nos ayuda a determinar en qué posición se encuentra Zambrano, y de factor, que nos señalará el camino que va a proseguir la joven filósofa. El boletín socialista puso énfasis en el carácter "discipular" de la relación Ortega-Zambrano -“discípula devotísima"-. Se recriminaba de modo implícito que Ortega se había desentendido de la cuestión social. Además, la nota hablaba de la primera carta crítica que Zambrano dirigió a Ortega ${ }^{74}$. De la cual Zambrano dice sólo haber hablado "a contados amigos que no creo que lo hayan referido". En la reseña, Cobos exhortaba a Ortega a: "Una cosa que ha de hacer el filósofo es no desentenderse de la política ¿Se desentenderá acaso de la ética? ¿Más tampoco de la política práctica, de la nacional, de la del día?"75. Para el socialista, ha sido la "nueva generación", la de sus discípulos, la que ha entrado de lleno en esa tarea ${ }^{76}$. Ortega todavía estaba al margen, incluso por encima de ella. Además, Cobos, que ha leído muy bien entre líneas, sabe que en el libro de Zambrano resuena de fondo la voz de Ortega pero aún más fuerte se pueden escuchar los ecos del gran maestro vasco y los institucionistas:

Es fortuna tener un profesor como Ortega; pero es más suerte de la juventud y bien de España que sea más maestro aún Unamuno. Y María Zambrano ha cuidado de tender el oído y la mirada en todas direcciones con oído y miradas atentos. Hacia Ortega, hacia Unamuno, hacia Cossío, hacia Marañón y Jiménez de Asúa, hacia Besteiro y de los Ríos, hacia Pérez de Ayala y Azorín ${ }^{77}$.

La concepción de lo popular que Zambrano presenta en Horizonte no puede entenderse sin las referencias esencialistas a Unamuno, a Machado, a la I.L.E, o al sentido humanista de Fernando de los Ríos ${ }^{78}$. En línea con lo que la joven Zambrano había aprendido directamente de su padre ${ }^{79}$, el pueblo español, lejos de los imaginarios del tradicionalismo, se hallará en las distintas corrientes heterodoxas que la Contrarreforma condenó a la intrahistoria española. Sólo el pueblo, no las masas, estaba capacitado para construir un ideal de comunidad política, un proyecto de regeneración nacional. El PSOE sería, para Zambrano, la manifestación/ revelación última del espíritu popular, del que tanto habló Machado, porque en él se entrecruzaban todas las corrientes que habían resistido a la España oficial que había petrificado la vida. Su preferencia pues por el socialismo español no era exclusivamente política sino más bien ontológica. Por ello, cuando Jiménez de Asúa le ofreció presentar su candidatura para las Cortes Constituyentes bajo el Partido Socialista, y ella hubo de elegir entre su vocación filosófica y su quehacer político finalmente declinó la oferta política. Tampoco aceptamos por tanto la interpretación de Monique Dorang sobre la afinidad entre el planteamiento zambraniano y

74 En un tono más tajante se asevera el desplante a Ortega: "Maestro: hay cosas que no se deben hacer nunca, que nunca las debe hacer nadie, y hay cosas que las pueden hacer todos menos algunos" (M. Zambrano, Tres cartas de juventud a Ortega y Gasset, op. cit., p. 18).

75 Ibidem, p. 17.

76 L. Robles Carcedo, “A propósito de 3 cartas de María Zambrano a Ortega”, Philosophica Malacita IV, 1991, pp. 231-239.

77 M. Zambrano, Tres cartas de juventud a Ortega y Gasset, op. cit., p. 18.

78 A. Bundgård, op. cit., p. $100 \mathrm{y}$ ss.

79 J. Sánchez-Gey, "Esperanza y agonía en Europa: María Zambrano", en A. Sánchez Cuervo, A. Sánchez Andrés y G. Sánchez Díaz (Coords.), María Zambrano. Pensamiento y exilio, Morelia, Universidad Michoacana de San Nicolás, Instituto de Investigaciones Históricas, Comunidad de Madrid, 2004, pp. 283-303. 
algunas propuestas marxistas ${ }^{80}$. No hay nada de comunismo en Zambrano, sino más bien un ideal comunitario interclasista.

De este modo, lo que para algunos autores es una carta exculpatoria de Zambrano y de justificación de cara al maestro, es a nuestro modo de ver un claro posicionamiento político frente a Ortega. Eguizabal indica que el modo en que "Cobos fuerza HL [Horizonte del liberalismo], es obvio" ${ }^{\text {. }}$. Lo fuerza en la medida que nuestra posición esté marcada por nuestra propia referencia al PSOE de aquel contexto. Dos años después, el PSOE derivaría a un partido de masas que se dirigía a la lucha de clases de la mano de Largo Caballero.

Entonces, Zambrano vería que la única posibilidad para su proyecto liberal pasaba otra vez por el "partido nacional" de Ortega. En una tercera carta fechada a 28 de mayo de 1932, ya constituido por tanto el Frente Español y en la que hace referencia a las críticas en el Parlamento de Ortega contra el Estatuto de Cataluña, Zambrano retornará "al magisterio iluminador" de Ortega, "tras la decepción de la militancia y el consiguiente repliegue" 82 . La carta termina con unas sentidas disculpas de justificación de su deriva socialista: "Tiene usted tantas cosas que perdonarnos a todos, que una más, no le costará excesivo trabajo" ${ }^{83}$.

La presión de Zambrano, su carta-manifiesto, causará el efecto deseado, pero no por la misma carta en sí sino por las circunstancias del momento que favorecerán que Ortega tomara el testigo como líder intelectual de la nueva generación. El filósofo romperá definitivamente con la tradición monárquica que declaraba agotada y moribunda y en un artículo publicado el 15 de noviembre de 1930 proclamará su conocido: Delenda est Monarchia. El famoso trabajo "El error Berenguer" abría el diario El Sol en su primera página ${ }^{84}$. No se tratará ya de agitar, sino de "definir y razonar" porque la Dictadura había fracasado y la Monarquía con ella. El tono de Ortega es diferente al artículo de primeros de años. Ahora sí está presente el carácter tajante que Zambrano le espetaba. Toda la Restauración era ahora una ficción, una absoluta "anormalidad en la historia humana". La Monarquía era ahora la culpable de haber agotado la vitalidad de España permitiendo un sistema dictatorial que había corrompido lo público. Lo privado invadía ahora todas las esferas de lo político produciendo una desnacionalización de lo público. Por ello, era un error la continuidad que se propiciaba de Primo a Berenguer, y de Berenguer a Aznar. Ésta era la divergencia con respecto a febrero. Para Ortega, la diferencia entre este artículo y el anterior se basaba en que la Monarquía pretendía continuar con la ficción en vez de iniciar un proceso de revitalización nacional, que el filósofo tanto había reaclamado. En esto consistía el error Berenguer. Si la Monarquía hubiera recorrido otro trazado, Ortega hubiera callado, pero persistía en su intención de continuar con la "ficción" nacional. Con Berenguer se demostró que no existía ya Estado español, y que la única posibilidad pasaba por "nacionalización" republicana. Con todo, el filósofo no

80 M. Dorang, "Una lectura marxista de la obra de María Zambrano", Philosophica Malacitana IV, 1991, pp. 101109.

81 J.I. Eguizabal, La huida de Perséfone. María Zambrano y el conflicto de la temporalidad, Madrid, Biblioteca Nueva, 1999, p. 39

82 M. Mallo, "María Zambrano: Tres cartas de juventud a Ortega y Gasset", Revista de Occidente 120, 1991, p. 12.

83 M. Zambrano, Tres cartas de juventud a Ortega y Gasset, op. cit., p. 26.

84 J. Ortega y Gasset, "El error Berenguer", El Sol, 15 de noviembre de 1930, en Obras Completa, Tomo XI. Madrid, Alianza Editorial, Revista de Occidente, 1983, pp. 274-279. Ahora recogido en J. Ortega y Gasset, Obras Completas. Tomo IV (1926-1931). Madrid, Taurus, 2017, pp. 760-765. 
había encajado el golpe de la discípula, como han indicado algunos autores ${ }^{85}$, sino que esperó a conocer la evolución de sistema español. En ningún caso el filósofo iba a evolucionar hacia las posiciones más izquierdistas de sus discípulos. Ortega sabía que, si la República nacía, habría muchas posibilidades de que tomará una deriva revolucionaria en las manos de un gobierno del PSOE. Su idea para España pasaba por un partido nacional, algo que en ese momento no podía ofrecer el PSOE de Largo Caballero. Por otro lado, los jóvenes discípulos ya se habían ido distanciando, adquiriendo cada uno su propia posición. José Díaz en la izquierda y Ramiro Ledesma en la extrema derecha son ejemplos paradigmáticos del fraccionamiento del universo orteguiano. Cuesta creer que se pudiera ejercer un liderazgo intelectual que pretendiese constituir un partido de masas entre polos tan enfrentados. De hecho, sería poco después cuando Azaña sustituyera a Ortega en el liderazgo de aquella generación.

\section{La monarquía debía ser destruida}

El eco de este artículo fue enorme. El trabajo se publicó en diversos diarios locales y extranjeros. Tres semanas después Ortega presentó su proyecto con el que acometía la tarea de reforma del país y reunir a las elites necesarias para ello ${ }^{86}$. Junto a Gregorio Marañón y Pérez de Ayala, Ortega asumiría la tarea de liderazgo intelectual en la Agrupación al servicio de la República ${ }^{87}$ (ASR). La ASR nació de cara a la opinión pública el 10 de febrero de 1931 con la aparición en el diario El Sol de su manifiesto fundacional. Aunque Margarita Márquez Padorno asegura en su monografía que el grupo estaba constituido un mes y medio antes y que Ortega estuvo trabajando durante este período en la manera de organizar un proyecto que agrupara a los intelectuales con la intención de intervenir en la vida pública y promover el proceso de "nacionalización" de España. Muy pronto la Agrupación alcanzaría los 25.000 miembros en todo el territorio. Pero su vida política no duraría mucho. Ortega la disolverá en octubre de 1932. Mediante la Agrupación, Ortega pretendía consolidarse como magíster del pronto constituido nuevo régimen.

El 14 de abril de 1931 se proclamará la II República española. En Delirio y destino Zambrano describe el suceso:

Había calma, una calma absoluta; nadie tenía que actuar sino aquellos que intentaban la salida más honrosa, que tendía el puente entre el pasado que se iba y el presente insoslayable. Y el pueblo, es decir, todos, España, toda esperaba, se retiraba en un último instante para dar aún ese minuto a quien debía tomar la resolución, para dejarle esa última acción ${ }^{88}$.

85 J. Moreno Sanz, op. cit., p. 122.

86 J. Ortega y Gasset, "Un proyecto", El Sol, 6 de diciembre de 1930, en Obras Completa, Tomo XI. Madrid, Alianza Editorial, Revista de Occidente, 1983, pp. 280-290 Ahora recogido en J. Ortega y Gasset, Obras Completas. Tomo IV (1926-1931). Madrid, Taurus, 2017, pp. 765-776.

87 Sobre esta empresa intelectual de Ortega véase: M. Márquez Padorno, La Agrupación al servicio de la República. La acción de los intelectuales en la génesis de un nuevo estado, Madrid, Biblioteca Nueva, p. 61.

88 M. Zambrano, Delirio y destino. Los veinte años de una española, op. cit., p. 1039. 
En aquellos instantes no se sabía si había abdicado el rey. "En verdad que nadie lo sabía ni nadie venía para decirlo; tampoco nadie lo preguntaba" 89 . Son momentos de "delirio", de "esperanza", para nuestra autora. Una voz "sonora", "como se cantan las verdades", proclamaba la República española, y el pueblo español parecía abrirse a aquella "razón vital" pregonada por Ortega. Para Zambrano, fueron intensos períodos de acción política, imaginaba el idilio de un pueblo que se reunía comunitariamente en ideales de plenitud. El pueblo, que no las masas, parecía por primera vez estar dotado de aquel "amor intelectual" que defendió Ortega en el 14:

Era la primera vez que una muchedumbre se congregaba ante un intelectual, ante un poeta; una muchedumbre compuesta de cada uno, como él quería, de individuos que no se diluían en una masa amorfa; hubiéramos querido verle más sereno y sacerdotal, pero... como le queríamos, le quisimos asi ${ }^{90}$.

La República era para Zambrano la culminación de la tarea de nacionalización emprendida por Ortega. Para la malagueña: "La nación se recreaba ahora al modo de la Epoca Moderna"91. Más bien, la República era la propia nación, fundida en pueblo y dirigida por aquellas minorías intelectuales que habían preparado el momento. Era la posibilidad de una auténtica revolución nacional. Zambrano veía en aquella experiencia política que nacía la posibilidad de dejar atrás la "temible España" que habían cantado los versos de Machado. Con ella, se esclarecía el horizonte de vuelta a la fracasada reforma religiosa del XVI, al erasmismo español ${ }^{92}$. Así, por una vez, saldría España de ese altar en el que Felipe II la sacrificó por el poder ${ }^{93}$. El desliz de Zambrano consistía en que no fue jamás capaz de percibir que el propio concepto de nación determinaría el acontecer mismo de la ulterior guerra civil. No se percató que el liberalismo no estaba en capacidad de ofrecer un concepto de nación a la naciente república. La nación sería pensada de manera distinta por los liberales, los socialistas, los carlistas o los falangistas. No existía en esta república principios algunos de consenso sobre los que construir un proceso constitutivo de largo recorrido tal y como luego se demostró. Ortega que se percataría de ello no tardó mucho en desligarse del régimen republicano. Para Zambrano, en cambio la República quedó como la matriz desde la que ella juzgaría la vida entera. La experiencia de la República pasaría a formar parte de su ontología vital.

Pronto se pudo comprobar el hecho de que la República iba por un lado, y la Agrupación-Ortega, por otro. Su conferencia del 8 de diciembre de 1931 "Rectificación de la República" expresaba su descontento con las políticas republicanas adoptadas. Ortega pidió allí un "Estado integral, superior a todo partidismo" y abogó por "un partido de amplitud nacional" que dirigiera la revitalización de España más allá de las izquierdas y las derechas. La Agrupación nunca sería ese partido. Al contrario,

\footnotetext{
Ibidem, p. 1044.

Ibidem, p. 999.

Ibidem, p. 997.
}

92 La República constituiría para Zambrano ese idilio largamente esperado de entroncar con Europa: "Mas en España la continuidad histórica estaba rota desde hacía tres siglos y esta acción, esta exigencia de un cambio de régimen no fue en nombre de ningunos principios originalmente revolucionarios, no fue para hacer la revolución, sino para hacerse a sí misma, para hacerse simplemente" (M. Zambrano, Delirio y destino. Los veinte años de una española, op. cit., p. 997).

93 Cf. M. Zambrano, Delirio y destino. Los veinte años de una española, op. cit., pp. 924-925. 
sus miembros para poder presentarse a las elecciones lo hicieron participando en las listas de la coalición republicano-socialista, como es el caso del propio Ortega. En cuanto a la posibilidad real de presentarse como partido como tal se fue diluyendo al cabo del tiempo. Ortega observó que la Agrupación se constituyó como frente de oposición común de los sectores republicanos ante la Monarquía, pero una vez que ésta había sido derrocada, los distintos partidos políticos se habían ido reforzando y diferenciándose unos de otros, quedando superado el carácter unitario de la Agrupación. El fundador de ASR pensaba que, de no constituirse "en forma que tenga algo de lo que se suele llamarse partido, sólo nos queda eso que se ha llamado educación cívica"94. Así sucedió. La ASR desapareció un año después de su formación por su propia incapacidad para constituirse como partido nacional y por la imposibilidad de Ortega para expresar su liderazgo sobre la generación joven. Lo que terminaría convirtiéndose en una constante, tal y como se verá con la creación del Frente Español.

El 7 de marzo de 1932 salía publicado el manifiesto de constitución del Frente Español (F.E.) en el diario madrileño La Luz. Consistirá en el último intento orteguiano de organizar la "decencia" en un partido nacional, vertebrar España y nacionalizarla. El manifiesto estaba firmado por María Zambrano Alarcón, Eliso García del Moral y Bujalance, Salvador Lissarrague Novoa, José Antonio Maravall, Antonio Riaño de Lanzarote, José Ramón Santeiro, Abraham Vázquez y Saénz de Hermúa. Sabemos también por Gibson que el manifiesto del nuevo grupo fue redactado por Alfonso García Valdecasas, procedente de la sección granadina de la ASR y diputado en las Constituyentes. La corrección fue tarea del propio José Antonio Maravall ${ }^{95}$. El manifiesto contó con el beneplácito de Ortega ${ }^{96}$. Según el jonsista Emiliano Aguado fue el propio Ortega quien fundó el Frente Español antes que sus iniciales pasarán a Falange ${ }^{97}$. Para Stanley G. Payne, de lo que se trató fue de recuperar la noción de "partido nacional" superador de los partidos que Ortega habría propagado en sus escritos políticos. A su modo de ver, "Valdecasas y sus amigos constituyeron el Frente Español, partido encaminado a salvar a la República de los dogmas de la derecha más intransigente, de la izquierda radical y del centro doctrinario" "98. De este modo, en línea con el filósofo madrileño el Frente Español se presentó como un partido político situado más allá de las izquierdas y derechas, que tenía como pretensión la de representar los intereses de toda la nación y superar la división de clases. Sus integrantes se sentían defraudados con el giro que la República estaba adoptando y aceptaban plenamente el "aldabonazo" de Ortega. No obstante, el manifiesto apenas tuvo repercusión en la opinión pública española, que en cambio sí destacó las intervenciones públicas del joven catedrático García Valdecasas ${ }^{99}$.

El manifiesto de constitución del Frente Español se presenta al público como "el llamamiento al país" de un grupo de jóvenes, que afirmaban que con el advenimiento de la II República se reveló como la posibilidad para que España recuperará "su ruta histórica". Sin embargo, el devenir republicano se muestra como una oportunidad perdida para España. El liberalismo "naturalista del s. XIX" heredero de la Dictadura era, según el panfleto, el culpable de la falta de vertebración de España, en

\footnotetext{
94 M. Márquez Padorno, op. cit., pp. 138-139.

95 I. Gibson, En busca de José Antonio, Barcelona, Editorial Planeta, 1980, p. 59.

96 Ibidem.

97 E. Aguado, Ortega y Gasset, Madrid, EPESA, 1970, p. 31.

98 S. G. Payne, Falange. Historia del fascismo español, París, Ruedo Ibérico, 1965, p. 21.

99 C. González Cuevas, op. cit., p. 323.
} 
tanto que rompió "la unidad del cuerpo social" y propició el desarrollo de la lucha de clases que ha desestructurado al Estado español. La República, en su parecer, no había sabido levantar un ideal nacional de bien común que evitase la lucha de las izquierdas contra las derechas. "Han ignorado que el interés de España está por encima de todo", remarcaba el acta constitutiva ${ }^{100}$. Igualmente, la República había caído en las luchas por la religión porque las fuerzas políticas no habían captado que el Estado nacional "no tiene misión religiosa alguna que cumplir". Así, los jóvenes orteguianos convocaban a la fundación de un partido interclasista y supranacional que culminé "la renación ( sic) española". Al mismo tiempo, el joven grupo clamaba la necesidad de la construcción de un sistema corporativo de trabajo, bajo la sindicalización de productores, con la elevación de los Sindicatos a organismos de gestión socio-económica del país. Llegados a este punto el grupo planteó que el Estado era una comunidad nacional donde toda esfera social debía de subordinarse al Estado que tenía como misión histórica "la expresión de su espíritu universal". Antonio Elorza, que acaba su libro pidiendo cuentas a Ortega por el descarrío de sus discípulos, ha indicado acertadamente que la huella del filósofo aparece inequívocamente en el texto, en donde la concepción comunitarista de la nación engarzará los planteamientos orteguianos con los de una idea de Estado totalitario ${ }^{101}$. En verdad, el texto puede leerse de manera vaga y amplia y acoger diversas lecturas. Desde la más estrictamente orteguiana a la puramente falangista. De ahí, precisamente, la variedad ideológica de los firmantes del manifiesto. No obstante, todos comparten un punto en común, la creencia en la existencia de una esencia eterna de España. En el fondo, estos jóvenes arrastran del liberalismo conservador del s. XIX una idea esencial de España que perdurará tanto en los escritos de Zambrano en el exilio, como en el programa de Falange o en los textos de Maravall sobre pensamiento español. La diferencia será, como arriba vimos, a la hora de establecer las relaciones de mando entre las masas y las elites, y las relaciones de poder entre el ejecutivo y el parlamento. Aquí es precisamente donde se verá el paso de lo liberal al fascismo que Ortega no consumó. Zambrano lo sabía perfectamente cuando en una entrevista en 1989 señalaba que:

Aquel grupo respondía a un programa muy ambicioso, y por ser tan ambicioso, ligeramente peligroso. Cuando se planteó la posibilidad de que él se añadiese la presencia de otras personas, para mí, ya se trataba de otra cosa. Como se sabía que FE estaba, más o menos inspirado por Ortega y don José nunca quiso recibir a José Antonio, me pareció que nosotros no teníamos derecho a hacerlo figurar. Luego como se manifestarán diversas tendencias en el grupo, renunciamos todos: se acabó la función ${ }^{102}$.

Precisamente, quien sí se hizo eco del manifiesto del Frente, fue el fundador de las Juntas de Ofensiva Nacional-Sindicalista (JONS), Ramiro Ledesma Ramos, que en una carta fechada a 12 de abril de 1932 escribe a su M(aestro) D. José Ortega y Gasset:

\footnotetext{
100 J. Moreno Sanz, op. cit., p. 160.

101 A. Elorza, La razón y la sombra, op. cit., p. 218.

102 Entrevista con J.C. Marset, "María Zambrano: «He estado siempre al límite»", Abc, 23 de abril de 1989, p. 71.
} 
¡De nuevo, amigo Don José, ha resucitado usted eso de partido nacional. Sólo comprendo un partido nacional a base de esgrimir como bandera ideales nacionales. ¿Pero no ocurre que usted llama a filas a gentes y grupos por esencia y definición antinacionales? ¿Es posible lo nacional sin un compromiso de guerra a muerte con lo masónico y marxista, por ejemplo? ¿Acaso lleve a la prensa estas interrogaciones a usted dirigidas? ${ }^{103}$.

Ledesma Ramos advirtió heterogeneidad del grupo, así como la necesidad, en su opinión, de someter el partido a la fuerza violenta del mito nacional. Como bien indica Zambrano, existían puntos en común -las críticas al liberalismo, la idea de partido nacional, el carácter irreligioso- pero también considerables diferencias, ora insalvables. El fracaso del Frente Español manifestará una vez más la impotencia de Ortega para hacerse con el liderazgo de una generación y su incapacidad para plantear un proyecto liberal de largo alcance. De hecho, según Zambrano relata en dicha carta, los orteguianos, o más bien los pocos liberales que así se llamaban habían derivado "a ser una secta"104, sin apenas intervención en la vida política española. Nadie escuchaba ya en España al maestro Ortega, todavía menos a su alumnado. A Zambrano le quedó a la sazón solamente el refugio de la Filosofía ${ }^{105}$. Su esencialismo irá ganando posiciones ante el fracaso de su compromiso político juvenil hasta derivar en un impolíticismo de raigambre gnóstica.

103 Carta de Ramiro Ledesma dirigida a José Ortega y Gasset, Archivo José Ortega y Gasset, R. 9, T. 3, carpeta 65, JK 54

104 M. Zambrano, Tres cartas de juventud a Ortega y Gasset, op. cit., p. 26.

105 Ibidem. 